\title{
Handbak eller stetoskop?
}

\author{
Livsstil og vegval er ulike. Me vil gjerne nøyde motparten inn i våre. Disiplin eller kaos, kroppsform \\ og matvanar, regresjon i rus eller fritid. Mangt er eigna til klassifisering og deretter høvande terapimål.
}

Narren er hjå oss oppfatta som ein tåpe, gjerne også som etisk forkasteleg. I mellomalderen var narren ein fristilt figur ved hoffet. Han bytte seg ut, men var innanfor. Han kunne løyse opp alvorlege og tunge stunder med komedie, latterleggjere eller insinuere. Lydaren kunne ta påstandane som fjas eller alvor, med glede eller sorg. Narren hadde rolla som refsar og trøystar, sannseiar og skrønemakar. Fjernsynskveldar nå til dags sender oss narrar inn i stovene. Me ler og blir forarga.

Bygdefylliken har hatt status som gjøglar, flåkjeft eller vismann, men har også vorte oppfatta som den uforbederlig forderva eller den botferdige realisten. Men han høyrde til, som ein kontrastfigur for bygda å spegle seg $i$.

Notidas bruk av illegal rus, med kriminalisert livsstil, utstøyting frå storsamfunnet og med personlegdomsforfall avlar ikkje den posisjonen.

Vår bygdedrankar er som Kain godt stigmatisert, han er freda. Trufast og energisk har han halde det fyrste bygdebod: Du skal arbeide! Helger eller kveldar i sløra ølrus vert lite kommentert eller vurdert, Mons er nå alltid Mons. Låke vener introduserte han for dei urbane variantane hasj, tablettar, sprøyter. Det vart eit heftig og usselt rusliv. Vener døydde. No er det ølet, i fleire sekspakkeeiningar, eller ein og annan rev.

Han vart fanga av gartnernaboen. Drivhusplanter var skada eller dandert på finurleg vis, eit merkeleg tiltak som vitna om både hevn og gjøn. Naboen vart lei av tullet. Han venta ei natt og tok Mons på fersk gjerning. Han kunne ha teke hevn, banka han dugeleg opp. I staden batt han Mons, sette han inn i kjêlhuset og sat i lag med han til morgonen kom. Mons var hjelpelaus andsynes naboen. Naboen skada han ikkje - ein nydeleg gestus. Vår ven lærte noko. Det vart uråd å herje med ein nabo som synte medynk og nåde.

Det hender han møter på kontoret. Han vert sjuk, han som andre. Men den fælaste sykja er mangel på rus. Her kan legen kome hendig inn.

Ein dag sit me der. Samtalen er komen til punktet for kjøp og sal. Eg prøver selje ein borgarleg livsstil, han vil kjøpa seg ei mjukare bakruslanding. Eg meiner eg har gode kort på handa, både fagleg og logisk. Forhandlingane dreg seg til og argumenta mine gjer ikkje inntrykk på han. Eg kjenner meg provosert og sinna. Det er eg som eig dette kontoret! Eg vil styre takt og tone. Men korkje medisinsk teori eller medisinsk praksis bit på han. Så føyser eg Felleskatalogen og stetoskopet bortetter kontorpulten og seier høgt: «Skal me bryte handbak?»

I det same det er sagt, støkk eg til. Tenk om den tidlegare karrieren min som turnar, mi daglege sykling og mitt varierande fri-

\section{«Han er min medborgar og narr, somme tider vismann, andre tider fåvis»}

luftsliv ikkje er nok til å greie med denne femten år yngre muskelbunten. Han er litt perpleks, men kjem med handa. Olbogane vert planta på slett bord.

No er vilkåra dei same for oss båe. Kven skal eige fagkunnskap og vere likeverdig samtalepartnar her? Handtaket fester seg og musklar gjer seg klare. Så knyter hendene seg. Underarmar, overarmar og aksler bular og hardnar. Fargen i andlet endrar seg, kvitauget raudnar, pusten skifter rytme, pultplata dirrar. Dette kan gå ille, jammen er han seig! Det går mot uavgjort, ei avgjerd eg ikkje kjenner meg klar for. Så tek eg i det eg vinn - han kjem på defensiven. Sakte bender eg han ned i bordet. Sjå det, kven eig dette kontoret? Eg minnest at han vart både overraska og brydd av resultatet.

Seinare har me hatt mange samtalar, mange tak om livet hans, helsa hans og rusen. Det har vorte eit betre samtaleklima, tykkjer eg. Eg vil nok ikkje lukkast i å få han rusfri, for det må det ikkje mindre til enn eit totalt byte av livsstil, ei omvending.

Han er min medborgar og narr, somme tider vismann, andre tider fåvis. Han provoserer, kritiserer og karakteriserer. Eg har fătt meg gode låttar.

I kampen om å minke rustrykket har eg fått ein uventa alliert! Levra hans har slite i mange år. Blodprøvesvar råkar oss som skræmeskot, vekselvis tek han innover seg alvoret eller bagatelliserer. Porfyrinstoff- skiftet har etter kvart fått nok. Han utvikla brennande og sviande sår på hender og $i$ andletet.

Etter ølperiodar og solskin lid han, vassblærer veks og sprekk, han er ufjelg å sjå på. Det er berre éin kur - ingen alkohol. Det kjem til ei personleg krise - anten velge å vere spedalsk og sjuk med ølliv og svirebrør eller utslettfri, betre i kroppen, ein fråhaldsmann i sosial isolasjon. Kva skal ein mann gjere når naturen

til dei grader går strafferundar med han?

Éin utveg er å vende seg til hampen. Me har ofte snakka om det alternativet. Men han hostar så ille etter røykedagane, og effekten fortek seg. Det både plager og skræmer.

Her kjem legen inn. Eit kompromiss er å få ete oksazepam i tilmålte dosar, inntil to om dagen. Den rusen kan han leve med, den kan halde borte angst og byllar, gjere han kvalifisert til sosialt samvær. Så slingrar me vidare, me to. Eg føreskriv og tel, han gjev rapport frå sine dagar og tider. Eg forhandlar om livsstil, han ordbryt med meg om sine svarte, grå og kvite livsval. Så slår me einannan på akslene, smiler og avtaler neste time.

«Mons» har samtykt til publisering.

\section{Aslak Bråtveit}

aslsigu@online.no

Aslak Bråtveit (f. 1951) er lege ved Finnøy legekontor, Finnøy.

Ingen oppgjevne interessekonfliktar.

Motteke 15.10. 2014 og godkjent 29.10. 2014. Redaktør: Erlend Hem. 